\title{
POLA ASUH ORANG TUA DALAM MENGEMBANGKAN POTENSI ANAK MELALUI HOMESHOOLING DI KANCIL CENDIKIA
}

\author{
Eli Rohaeli Badria1, Wedi Fitriana ${ }^{2}$ \\ 1,2 IKIP Siliwangi \\ 11rohaels@yahoo.com
}

\begin{abstract}
Abstrak
Pendidikan merupakan proses belajar yang berlangsung sepanjang hayat dan memiliki tujuan agar manusia dapat berkembang lebih utuh. Orang tua adalah orang utama yang bertanggung jawab terhadap pendidikan anak, namun orang tua juga memiliki keterbatasan sehingga tidak dapat memenuhi kewajibannya. Sekolah publik merupakan tempat untuk membantu orang tua memenuhi tanggung jawab tersebut. Beberapa penyebab mengindikasikan bahwa sebagian anak justru mengalami kegagalan untuk berkembang sesuai dengan potensi dan keunikannya di sekolah. Untuk itu pendidikan formal butuh keterlibatan pendidikan informal untuk meningkatkan dan menjawab kebutuhan dan menutupi keterbatasan tersebut. Salah satu keberadaan pendidikan informal yang mulai diakui dan dapat dijadikan alternatif adalah homeschooling. Tujuan penelitian ini dilakukan untuk mengetahui hal apa saja yang akan mempengaruhi melejitkan potensi anak atau pola asuh seperti apa saja yang mempengaruhi agar anak dapat berkembang sesuai harapan orang tua dan menjadi dirinya. Metode yang digunakan yaitu metode deskriptif dan metode sosial. Hasil yang ditunjukan melalui penelitian ini yaitu anak menjadi lebih percaya diri dengan keberadaan dirinya dan mampu mengekspresikan dirinya lewat karya yang diminatinya dengan metode Authoritatif Parenting atau kemandirian.
\end{abstract}

Kata kunci: Authoritatif Parenting , Homeshooling, Pendidikan informal

\section{A. PENDAHULUAN}

Penelitian dilakukan bedasarkan terdapat pola asuh yang berbeda disetiap orang tua yang menyebabkan berbeda pula hasil didik yang didapat yang kadang-kadang tidak sesuai dengan yang diharapkan orang tua itu sendiri. Oleh karena itu penulis akan mencoba sharing tentang hal apa sajakah yang akan membuat potensi anak dapat berkembang dengan baik sesuai dengan harapan baik orang tua maupun anak itu sendiri. Tujuan yang ingin didapat oleh penulis yaitu ingin mengetahui hal-hal apa saja atau pola asuh seperti apa saja yang dilakukan agar potensi anak bisa tergali atau anak lebih ekspresif atau bisa paham akan kemampuan atau potensi yang dimilikinya sehingga bisa lebih mudah dalam mengaktualisasikan dirinya dimasa yang akan datang. Penelitian sejenis pernah penulis lakukan tetapi lebih fokus terhadap gaya belajar siswa dirumah dengan bantuan orang tua dan soal atau materi diberikan dengan system online. Tetapi hasilnya hanya sebatas kecerdasan IQ yang didapat. 


\section{B. KAJIAN TEORI}

"Izinkan mereka melakukannya sendiri" itulah yang bisa ditanamkan dalam benak seorang pengasuh tentunya dengan bimbingan. Hasil penelitian yang telah dilakukan mengenai melatih kecerdasan dengan belajar mandiri dengan memfokuskan pada kecerdasan IQ saja, hasilnya mungkin bisa memuaskan tetapi ada hal yang lebih penting dalam menghadapi kehidupan dimasa depan anak -anak yaitu diperlukan kemandirian.

"Menanamkan perilaku baik, menghilangkan perilaku negatif". Mengapa pentingnya pengenalan tahapan ini? Karena pengenalan karakter dan perilaku-perilaku baik memang dimulai sejak awal bayi lahir.

Menurut Erik Erikson (1963), ada 8 tahap perkembangan psikosial manusia:

\section{a. Trust vs Mistrus}

Tahap ini berlangsung pada masa oral, pada umur 0-1 tahun atau 1,5 thn.Poin pembentukan karakter yang harus diperhatikan pada masa ini adalah membuat bayi percaya kepada lingkungan. Dalam Islam, fase ini adalah masa bayi ( 0 hingga 2 tahun). Pada fase ini orang tua anak perlu untuk mengembangkan kasih sayang secara dua arah_dimana ibu memberikan kasih sayangnya dan dalam waktu bersamaan juga menstimulus/ mengembangkan kemampuan anak memberikan respon terhadap kita. Caranya yaitu:

1) Caregiver SIAP untuk SELALU bersikap penuh kasih sayang, lembut dan sabar kepada anak.

2) Peka kebutuhan bayi. Tetap sabar, penuh kasih sayang, dan lembut dalam menstimulus fisik anak, menerima perasaan-perasaan bayi dan tidak membiarkan bayi menangis terlalu lama.

3) Tidak membandingkan-bandingkan perkembangan bayi karena tiap bayi punya perkembangan unik masing-masing.

4) Komunikatif dengan bayi.

5) Perbanyak sentuhan fisik yang penuh kasih sayang, pelukan, ciuman, usapan, belaian, dan lain-lain.

6) Perbanyak juga kata-kata positif.

b. Otonomy vs shame and doubt (Otonomi vs perasaan malu dan ragu-ragu)

Tahap ini berlangsung mulai usia 1-3 tahun (early childhood). Dalam Islam, masa anak-anak (2-7 tahun atau disebut dengan fase thufulah) Pada fase inilah merupakan fase penting memberikan pondasi dasar tauhid pada anak melalui cara aktif agar anak terdorong dan memiliki tauhid aktif dimana anak mau melakukan sesuatu yang baik semata menurut Allah. Fase ini fase penting penanaman pondasi bagi anak. Poin pembentukan karakter yang harus diperhatikan pada masa ini adalah membuat anak percaya diri. Caranya adalah:

1) Caregiver selalu berkata- kata positif, siap untuk menyemangati anak ketika melakukan sesuatu, memberikan pujian, bersyukur, berterimakasih untuk anak.. dan 
tentunya, penting bagi caregiver untuk punya stok perbendaharaan kata yang tepat untuk setiap situasi.

2) Menyiapkan rumah yang aman agar anak mendapatkan kesempatan yang seluasluasnya untuk bereksplorasi.

3) Berempati dan melatih anak-anak untuk mengenali emosinya. apakah ia sedang marah, kesal, senang, sedih, bahagia, dan lain-lain.

4) Sejak anak memasuki usia 2 tahun, fase ini adalah waktunya bagi orang tua mengenalkan 'peraturan' tegas dan konsisten namun tetap dengan penuh kelembutan dan kasih sayang, karena masa-masa ini apalagi setelah fisiknya lebih sempurna, anak akan akan semakin giat mengeksplorasi ini itu dan kita akan mulai mengalami sendiri bagaimana tantrum pada anak. Mengapa sejak awal kita harus lembut?

Karena harapannya, sejak awal kita ingin memiliki anak yang berhati lembut. sehingga kalau anak 'macam-macam' di usia ini dan ke depannya, kita tidak perlu memarahinya untuk mengingatkannya.

5) Orang tua terus berlatih untu berpikir positif, tidakjudging apalagi labeling.

\section{c. Inisiatif vs Kesalahan}

Tahap ini dialami anak pada usia 4-5 tahun. Anak-anak pada usia ini mulai berinteraksi dengan lingkungan sekitarnya sehingga menimbulkan rasa ingin tahu terhadap hal yang dilihatnya, mereka menganbil banyak inisiatif dari rasa ingin tahu yang dimilikinya.

\section{d. Kerajinan vs Inverioritas}

Tahap ini merupakan tahap laten yaitu usia 6-12 tahun. Ditingkat ini anak mulai keluar dari lingkungan keluarga ke lingkungan sekolah, sehingga semua aspek mempunyai peran semisal orang tua harus selalu mendorong, guru harus memberikan perhatian dan lingkungan teman harus menerimanya.

\section{e. Identitas vs kekacauan Identitas}

Tahap ini merupakan tahap adolense, (usia 12-18/ remaja). Pada tahap ini mulai tahap puber, Tahap ini lingkungan semakin meluas tidak hanya dilingkungan keluarga atau sekolah tetapi juga dimasyarakat. Pencarian jati diri mulai berlangsung pada tahap ini

\section{f. Keintiman vs Isolasi}

Tahap ini terjadi pada masa dewasa awal yaitu usia antara 18-30thn. Dalam tahap ino keintiman harus seimbang untuk menumbuhkan nilai positif yaitu cinta, baik cinta terhadap keluarga, teman, saudara, binatang, dan lain-lain.

\section{g. Generativitas vs Stagnasi}

Masa dewasa tengah dimulai dari 20-an sampai 50-an, (middle audult). Dalam tahap ini terdapat salah satu tugas yang harus dicapai yaitu mengabdikan diri guna mencapai keseimbangan yaitu antara melahirkan sifat sesuatu (Generatifitas) atau tidak melakukan apa-apa (Stagnasi).

\section{h. Integritas vs Keputusasaan}


Tahap ini merupakan tahap usia senja (usia Lanjut). Tahap ini merupkan tahap yang sulit dilewati karena orang pada tahap ini cenderung introspeksi diri, mereka akan memikirkan kembali hal-hal yang telah terjadi pada masa sebelunya, baik itu keberhasilan ataupun kegagalan.

\section{PEMBAHASAN}

\section{Pengertian Pola Asuh Orang Tua}

Pola asuh orang tua adalah pola perilaku yang diterapkan pada anak dan bersifat relatif konsisten dari waktu ke waktu. Pola perilaku ini dapat dirasakan oleh anak baik negative maupun positifnya. Pola asuh orang tua merupakan gambaran tentang sikap dan perilaku orang tua dan anak dalam berinteraksi, berkomunikasi selama mengadakan kegiatan pengasuhan. Setiap orang tua mempunyai pola asuh yang berbeda, oleh karena itu akan menghasilhan pola hasil yang berbeda pada setiap anak, atau anak akan memiliki karakter yang berbeda antara satu dengan yang lainnya.

Dalam kegiatan memberilkan pengasuhan ini, orang tua akan memberikan perhatian, peraturan, disiplin, hadiah, dan hukumkan serta tanggapan terhadap keinginan anaknya. Sikap, perilaku dan kebiasaan orang tua selalu dilihat, dinilai dan ditiru oleh anaknya yang kemudian secara sadar dan atidak sadar akan diresapi da menjadi kebiasaan bagi anak-anaknya.

\section{Macam-macam Pola Asuh Orang Tua}

Menurut Baumrind (1967) terdapat empat pola asuh orang tua terhadap anaknya yaitu:

\section{a. Pola asuh Demokratis}

Pola asuh demokratis adalah pola asuh yang memprioritaskan kepentingan anak, akan tetapi tidak ragu-ragu mengendalikan mereka. Orang tua tipe ini juga bersikap realistis terhadap kemampuan anak, tidak berharap berlebihan yang melampaui kemampuan anak dan memberikan kebebasan kepada anak untuk memilih dan melakukan suatu tindakan. Pengaruh pola asuh demokratis akan menghasilkan karakteristik anak yang mandiri, dapat mengontrol diri, mempunyai hubungan baik dengan teman-temannya.

\section{b. Pola Asuh Otoriter}

Pola asuh otoriter adalah pola asuh yang cenderung menetapkan standar yang mutlak harus dituruti. Orang tua tipe ini cenderung memaksa, memerintah, menghukkum. Orang tua beranggapan bahwa anak harus mengikuti aturan yang ditetapkan, karena peraturan yang ditetapkan orang tua semata mata demi kebaikan anak.

Orang tua tak mau repot berfikir bahwa peraturan yang kaku justru akan menimbulkan serangkaian efek. Pola asuh otoriter biasanya berdampak buruk pada anak, biasanya pola asuh seperti ini akan menghasilkan karakteristik anak yang penakut, pemdiam, tertutup, gemar menentang, suka melanggar norma-norma, dan berkepribadian lemah.

\section{c. Pola Asuh Permisif}

Pola asuh ini memberiakan pengawasan yang sangat longgar memberikan kesempatan kepada anaknya untuk melakukan sesuatu tanpa pengawasan yang cukup 
dari orang tua. Mereka cenderung tidak menegur atau memperingatkan anak apabila ank sedang dalam keadaan bahaya, dan sangat sedikir bimbunhgan yang diberikan oleg mereka. Namun orang tua tipe ini bersifat hangat sehingga seringkali disukai oleh anak. Pola asuh permisif akan menghasilkan karakteristik anak yang tidak patuh, manja, kurang mandiri, mau menang sendiri dan kurang percaya diri.

\section{d. Pola Asuh Penelantar}

Orang tua tipe ini pada umumnya memberikan waktu dan biaya yang sangat minim pada anak-anaknya. Waktu mereka banyak digunakan untuk keperluan pribadi mereka seperti bekerja. Pola asuh penelantar akan menghasilkan karakteristik anak-anak yang agresif, kurang bertanggung jawab, tidak mau mengalah, sering bolos dan bermasalaah dengan teman.

\section{e. Pengaruh Pola Asuh Orang Tua Dalam Mengembangkan Potensi anak}

Pola asuh yang paling ideal yang mempengaruhi dalam perkembangan potensi anak adalah pola asuh yang pertama yaitu pola asuh demokratis. Dimana anak diprioritaskan, diperhatikan, serta ditanamkan hal-hal yang positif sejak dini dan dijauhkan dari hal-hal yang negatif. Meskipun tidak menutup kemungkinan pola-pola yang lain juga akan menghasilkan sebagian generasi yang berhasil dengan segala tekanan dan keterbatasanya. Sebagai orang tua, kita tentu berharap bisa memiliki anak yang cerdas dan berprestasi.

Apakah benar demikian bahwa hanya anak yang ber-IQ tinggi dan berasal dari keluarga kaya yang bisa meraih keberhasilan dan kesuksesan? Jawabannya adalah tidak! Bukan karena IQ tinggi dan dukungan fasilitas lengkap yang menentukan keberhasilan seorang anak, meskipun tak dipungkiri hal ini ikut berperan. Karena kenyataan membuktikan banyak orang yang sukses di usia dewasa justru berasal dari keluarga tidak mampu. Banyak orang-orang sukses dan berhasil menjadi pemimpin bukan karena kecerdasan otaknya, melainkan karena pengalaman dan kepribadiannya. Mereka mungkin berasal dari keluarga sederhana, dalam bimbingan dan tuntunan orang tua yang arif bijaksana, yang mengajarkan nilai-nilai kehidupan positif, sehingga mereka pun tumbuh menjadi pribadi yang matang dan dewasa.

Mereka mampu mengembangkan bakat dan potensi, serta ketrampilannya karena diberi kebebasan dalam mengekspresikan harapan dan cita-citanya. Jadi bagi para orang tua tak perlu berkecil hati jika anaknya tidak memiliki prestasi akademik yang tinggi. Sebab, mereka masih bisa meraih prestasi di bidang lain. Seperti mungkin dalam bidang seni, ketrampilan, olah raga, dan bidang lainnya.

Yang diperlukan dari orang tua adalah bagaimana memberikan perhatian kepada anak-anak agar mereka bisa mengembangkan bakat dan potensinya dengan baik. Untuk membina dan mengembangkan bakat si kecil orang tua bisa memulainya sejak usia dini. Yakni usia antara 0-4 tahun (usia golden age). Yang perlu diperhatikan dari anak adalah seberapa jauh anak merasa diperhatikan, diberi kebebasan atau kesempatan untuk mengekspresikan ide-idenya, dihargai hasil karya atau prestasinya, didengar isi hatinya, tidak ada paksaan atau tekanan, ancaman terhadap dirinya dan mendapatkan layanan pendidikan sesuai tingkat usia dan perkembangan kejiwaannya.

Pada usia mulai umur empat sampai enam tahun dikenal dengan usia wonder age orang tua mesti memberikan rangsangan/stimulus untuk mengembangkan kecerdasannya. Rangsangan pada anak usia itu antara lain memberikan sentuhan, menunjukkan warna-warni, atau mendengarkan suara hingga otaknya optimal 
menerima dan mempengaruhi kendali tubuh termasuk otak kanan dan kiri. Oleh karena itu tidak usah heran jika ada anak yang sehari-harinya belajar sangat pinter dengan nilai-nilainya yang bagus, namun kurang bersosialisasi atau tidak berani, takut, merasa malu ketika berdiskusi atau menyampaikan pendapat. Anak menjadi self relation atau hanya mampu bersosialisasi dengan dirinya saja tanpa dengan orang lain.

Anak-anak yang tumbuh dalam tekanan-tekanan, misalnya rasa takut, khawatir, stress, dan sebagainya ketika remajanya akan merasakan suatu dorongan-dorongan agresif atau nakal yang menimbulkan efek negatif. Mungkin anak itu kreatif tetapi kreatifitasnya menuju ke arah yang negatif, bahkan bisa ke arah sadis.

Tetapi jika anak-anak diperhatikan (care), bahkan sejak masa bayi hingga muncul rasa semangat, maka petumbuhannya akan sangat teratur sekali sehingga dia berpikir logis, lebih memperhatikan (care) kepada orang lain. Ibu memiliki peran sangat besar terhadap pendidikan anak-anak mulai sejak bayi. Ketika beranjak lebih besar lebih bagus jika anak itu dikirimkan ke child care atau kelompok bermain.

Namun demikian yang diperlukan dari seorang ibu adalah tahu cara mengasuh anak karena itu bagian dari tujuan pendidikan, sehingga anak-anak akan tumbuh dengan baik bukan hanya secara fisik saja tetapi juga berkembang secara psikologisnya dan secara neurosis.

Pendidikan di Sekolah Pendidikan selalu identik dengan sekolah atau lembaga pendidikan formal. Bahkan sekolah dianggap sebagai kebutuhan pokok yang harus dirasakan oleh anak dan tidak dapat digantikan dengan apapun. Sekolah dianggap sebagai sarana untuk tercapainya keberhasilan dalam mengarungi hidup dan kehidupan.

Faktor lainnya adalah pendidikan keluarga di rumah (Homeshooling) karena pendidikan bermula dari keluarga yang dianggap sama pentingnya karena sekolah memiliki beberapa kelemahan. Kelemahan ini menyebakan sekolah tidak dapat menumbuhkembangkan potensi anak secara optimal. Akibatnya tujuan pendidikan untuk mendewasakan, memandirikan anak menjadi terbatas oleh waktu dan ruang tersebut. Sekolah pun tidak dapat mengambil alih sepenuhnya peran orang tua dalam mendidik anak, terutama dalam hal menanamkan nilai-nilai yang dianggap penting seperti pendidikan nilai, moral, sosialisasi, dan agama.

Sedangkan sekolah lebih dominan pada pemberian ilmu pengetahuan yang bersifat akademik atau aspek kognitif saja. Orang tua sebenarnya bisa lebih mengarahkan perkembangan dan pertumbuhan anak sesuai dengan bakat dan minat, karena orang tua akan langsung tahu sejauh mana anaknya belajar.

Seorang ahli bernama Bronfenbrenner (1974) mengatakan bahwa kesejahteraan psikis dan fisik serta pendidikan anak sangat bergantung pada sejahtera atau tidaknya keluarga. Apabila keluarga gagal untuk mengajarkan kejujuran, semangat, keinginan untuk menjadi terbaik, dan kemampuan-kemapuan dasar, maka akan sulit sekali bagi lembaga-lembaga lain untuk memperbaiki kegagalannya.

Seorang anak dalam proses tumbuh kembangnya dipengaruhi oleh lingkungan keluarga, dan setelah itu oleh lingkungan diluar keluarga. Peran keluarga dalam pendidikan, sosialisasi dan penanaman nilai kepada anak sangat besar. Keluarga kuat adalah keluarga yang dapat menciptakan generasi-generasi penerus yang berkualitas dan berkarakter kuat, sehingga menjadi pelaku-pelaku kehidupan di masyarat. Kesuksesan orang tua membimbing anaknya dalam mengatasi konflik kepribadian di 
usia dini sangat menentukan keberhasilan anak dalam kehidupan sosial di masa dewasanya kelak.

Segala perilaku orang tua, pola asuh, dan pendidikan yang diterapkannya di dalam keluarga pasti berpengaruh dalam pembentukan kepribadian anak. Perilaku itu antara lain kasih sayang, sentuhan, kedekatan emosi (emotional bonding) orang tua serta penanaman nilai-nlai yang dapat mempengaruhi kepribadian anak. Membiasakan mendidik anak sejak kecil dapat membuahkan hasil yang terbaik. Sebaliknya membiasakannya ketika dewasa sangat sulit, seperti dalam sebuah

Thomas Licona (Depkominfo, 2006) mengungkapkan bahwa walaupun jumlah anakanak hanya $25 \%$ dari jumlah penduduk, tetapi menentukan $100 \%$ masa depan. Anak menjadi agen perubahan bagi pembentukan kehidupan masa depan, bahkan masa depan sebuah bangsa.

Pada usia dewasa nanti menjadi sumber daya manusia yang tidak bisa bekerja, atau tidak terampil. Anak tidak menghargai pekerjaan yang memerlukan keterampilan, kerajinan, ketekunan, kerja keras dan cerdas, percaya diri dengan kemampuan sendiri. Selain itu karena tujuannya mencetak anak pandai di bidang akademik kognitif, maka materi pelajaran yang berkaitan dengan otak kiri saja yang diperhatikan yaitu bahasa dan logis matematik.

Padahal banyak materi pelajaran yang berkaitan dengan otak kanan (kesenian, musik, lukis) kurang mendapat perhatian. Kalaupun ada perhatian, maka orientasinya juga lebih pada kognitif berupa hafalan, tidak ada apresiasi dan penghayatan yang dapat menumbuhkan semangat untuk belajar.

Tujuan pendidikan adalah membentuk anak agar senang dan termotivasi untuk terus belajar seraya bermain. Lebih menekankan pada penyiapan kecerdasan emosi sehingga anak diberi kesempatan untuk berkembang secara alami. Anak lebih senang bermain yang dapat mengembangkan fungsi otak kanan, sehingga akan memudahkan anak menguasai pelajaran yang diberikan guru.

Anak mengalami proses social emotional learning (kecerdasan emosi), joyful learning (belajar yang menyenangkan), dan active learning (anak terlibat aktif). Anak bukan sekedar objek tetapi subjek pendidikan. Oleh karena itu guru di sekolah dan orang tua di rumah seharusnya memberikan lingkungan yang dapat menumbuhkan rasa senang dan gembira seolah-olah mereka sedang bermain, padahal sebenarnya sedang belajar. Guru atau orang tua perlu memberikan bekal yang penting bagi anak, yaitu menciptakan kematangan emosi-sosialnya, karena dengannya seseorang akan dapat berhasil dalam menghadapi segala macam tantangan, termasuk tantangan untuk berhasil secara akademik

Berdasarkan temuan yang diperoleh dari lapangan, terhadap bentuk pola asuh permisif, ada dua orang informan yang sama-sama menerapkan bentuk pola asuh permisif, dalam mengasuh anak-anak mereka ada menerapkan aturan tapi aturan yang diterapkan itu tidak pernah di jalankan, setiap ada keinginan selalu dipenuhi dan saat anak melakukan kesalahanpun dianggap biasa karena anak masih belum mengerti karena usia anak masih cukup dini. Dalam berperilaku anak dari kedua informan ini tampak kurang baik, dan menunjukkan sikap suka menang sendiri dan berbicarapun dengan intonasi dan bahasa yang kurang baik. 


\section{KESIMPULAN}

Dengan uraian diatas penulis menyimpulkan bahwa pola asuh yang mendekati yang dapat mengembangkan potensi anak melalui homeshooling yaitu pola asuh demokratis dimana anak diprioritaskan, diperhatikan, ditanamkan hal-hal yang positif dan dijauhkan dari hal-hal yang negatif.

\section{E. DAFTAR PUSTAKA}

Baumrind, D. 1967. Child Practicies Antecendeing Three Patterns of Preschool Behacior. [online].

Tersedia

http://www.devpsy.org/teaching/parent/baumrind styles.html. Diakses : 27 Maret 2014

Bronfenbrenner. 1974. A Report on Longitudinal Evaluation of Preschool Programs, Volume III: Is Early Intervention Effecvtive? Washington DC; Office of Child Development, Departmen of Health, Education and Welfare.

Erikson, E. 1963. Definisi Main Peran Mikro dan Makro kerjasama Dit PADU, Ditjen PLSP, depdiknas Sekolah Alfalah, Jakarta Timur dan CCCRT 2004. 